\title{
Development and Validation of a Method for the Quantification of an Alkaloid Fraction of Himatanthus lancifolius (Muell. Arg.) Woodson by Ultraviolet Spectroscopy
}

\author{
Patrícia M. S. S. Barros, ${ }^{1}$ Nádia M. G. de Couto, ${ }^{2}$ \\ Andressa S. B. Silva, ${ }^{3}$ and Wagner L. R. Barbosa ${ }^{1,2,3}$ \\ ${ }^{1}$ Programa de Pós-Graduação em Ciências Farmacêuticas, Instituto de Ciências da Saúde, Universidade Federal do Pará, Brazil \\ ${ }^{2}$ Laboratório de Fitoquímica, Faculdade de Farmácia, Instituto de Ciências da Saúde, Universidade Federal do Pará, Brazil \\ ${ }^{3}$ Programa de Pós-Graduação em Inovação Farmacêutica, Instituto de Ciências da Saúde, Universidade Federal do Pará, \\ Rua Augusto Corrêa No. 01, Guamá, 66075-170 Belém, PA, Brazil
}

Correspondence should be addressed to Wagner L. R. Barbosa; barbosa@ufpa.br

Received 12 July 2013; Accepted 26 September 2013

Academic Editor: Tingyue Gu

Copyright (C) 2013 Patrícia M. S. S. Barros et al. This is an open access article distributed under the Creative Commons Attribution License, which permits unrestricted use, distribution, and reproduction in any medium, provided the original work is properly cited.

\begin{abstract}
For the registration of phytomedicines and their availability to the population, National Agency of Sanitary Surveillance (ANVISA) establishes quality, security, and efficacy parameters, stipulating control requirements similar to those applied to synthetic medicines. This work reports the investigation of the bark of Himatanthus lancifolius and its extracts aiming to contribute to the standardization of derivatives of this plant species. The developed quantification method shows high selectivity at $281 \mathrm{~nm}$, which confers confidence to the detection of the alkaloids. The method is robust, according to the current regulation, and shows linearity, precision, and accuracy, beside accessibility and simplicity in execute. The $\mathrm{pH} 10$ alkaloid fraction obtained from the aqueous extract of the analyzed sample represents $0.219 \%$ in the dried extract. These results contribute for reducing the lack of methods for the quality control of phytomedicines prepared from H. lancifolius.
\end{abstract}

\section{Introduction}

Apocynaceae include about 450 genus and 4,950 species with pantropical distribution which, in Brazil, are represented by three subfamilies: Asclepiadoideae, Rauvolfioideae, and Apocynoideae [1]. They occur in grassland and forest including about 60 genus and 750 species [2]. The presence of latex in the reproductive and vegetative organs besides flowers with contort prebudding is characteristic patterns of the Apocynaceae [3]. Carl Willdenow and Josef Schultes described genus Himatanthus, and it includes only 13 species, all of them found in South America, mainly in Amazonia [4]. This genus was erroneously referred to as Plumeria up to 1938 when Woodson Jr. in "Studies in the Apocynaceae: an evaluation of the genera Plumeria L. and Himatanthus Willd." reported that the aboriginal Himatanthus species from South
America were morphologically different from those Plumeria found in North and Central America [5].

According to the Brazilian regulation on phytomedicines herbal materials can be standardised on the basis of a metabolic class, a specific group of substances, which here is a $\mathrm{pH} 10$ alkaloid fraction aiming to guarantee the chemical homogeneity of each batch of the herbal product $[6,7]$.

$H$. lancifolius, vernacular agoniada, has its bark frequently used as a decoction to treat uterine congestions, irregular, difficult, and painful menstruations, pains and uterine spasms, ovaries and uterus inflammations, menstrual interruption, dizziness, stomach disorder, headache, fatigue, flatulence, and "dor nas cadeiras," the pain connected to uterine inflammations [8]. Like many other emmenagogue plants, there are reports of the use of H. lancifolius as abortive [9]. 
In order to guarantee higher effectiveness and safety to the users of herbal medicines, applying quality criteria defined by the National Agency of Sanitary Surveillance (ANVISA), it is necessary to carry out studies aiming at a validated standardization of the aqueous extract of the bark of $H$. lancifolius.

\section{Materials and Methods}

2.1. Materials. Brazilian Agricultural Research Corporation (EMBRAPA) provided the plant material collected in the morning. A herborized specimen was accurately compared to the exsiccatum number 183977, deposited at the North Agronomic Institute (IAN), and it could be characterized as H. lancifolius (Muell. Arg.) Woodson. The bark had moss and dirtiness, removed by scraping; the cleaned material was then washed with ethanol $96^{\circ} \mathrm{GL}$ and then cut in small pieces. After the extraction, the fragments were left to dry at $40^{\circ} \mathrm{C} \pm 2^{\circ} \mathrm{C}$ under forced hot air circulation.

2.2. Experimental Procedures. The dried fragments of bark were ground in a Wiley knives' mill. Using the electromagnetic sieve stirrer Bertel the averaged particle size of the herbal drug could be determined by stirring $10 \mathrm{~g}$ of the drug in a series of sieves with the following meshes opening: $1.40 \mathrm{~mm}$ and $710,355,250,180$, and $125 \mu \mathrm{m}$ for $30 \mathrm{~min}$., weighing the powder retained in each sieve [10].

To $1000 \mathrm{~mL}$ ultrapure boiling water, $50 \mathrm{~g}$ of powdered bark was added in order to obtain the aqueous extract after another $10 \mathrm{~min}$ boiling [11]. After cooling, the mixture was filtered under reduced pressure. The aqueous extract (AEHL) was concentrated under reduced pressure and dried at about $45^{\circ} \mathrm{C}$ for $48 \mathrm{~h}$.

Circa $50 \mathrm{mg}$ of AEHL was treated with $40 \mathrm{~mL}$ of $1 \%$ $\mathrm{HCl}$. The filtered acid solution was basified with ammonium hydroxide to $\mathrm{pH} 10$, then proceeding to a liquid-liquid partition employing four $10 \mathrm{~mL}$ aliquots of chloroform. The fractions were blended, dried over anhydrous sodium sulfate, and concentrated in a water bath without heating, under reduced pressure, ending the drying in a desiccator under vacuum. A $30 \mathrm{mg} / \mathrm{mL}$ methanol solution of this fraction was used to determine the content of total alkaloids at $281 \mathrm{~nm}$.

Methanolic (UV-HPLC-VETEC) solutions at 16, 18, 20, $22,24,26$, and $28 \mu \mathrm{g} / \mathrm{mL}$ of Yohimbine hydrochloride (Indo Phytochem Pharmaceuticals 99.02\%) were used to determine the method linearity and to define the calibration curve.

All parameters adopted are in accordance with the guide for validation of analytical and bioanalytical methods number 899/2003 from ANVISA.

The method selectivity test was performed using a $30 \mu \mathrm{g} / \mathrm{mL}$ methanolic (UV-HPLC-VETEC) solution of AEHL; the above described $22 \mu \mathrm{g} / \mathrm{mL}$ Yohimbine hydrochloride methanolic solution and UV-HPLC methanol (VETEC) under UV light between $200 \mathrm{~nm}$ and $400 \mathrm{~nm}$.

To determine the method linearity, the absorbance of methanol solution of yohimbine hydrochloride (above) at $16,18,20,22,24,26$, and $28 \mu \mathrm{g} / \mathrm{mL}$ was measured in quintuplicate. The results were statistically analyzed to define

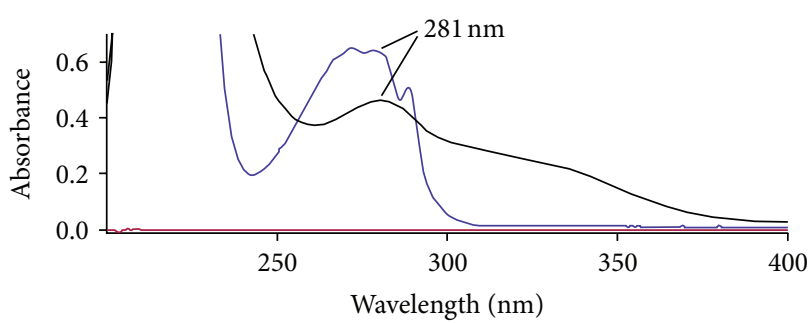

FIGURE 1: Selectivity of the method developed for the alkaloid fraction of $H$. lancifolius $(30 \mu \mathrm{g} / \mathrm{mL})$ (a) with yohimbine hydrochloride $(22 \mu \mathrm{g} / \mathrm{mL})$ as reference (b) and the methanol as solvent (c) observed between 200 and $400 \mathrm{~nm}$.

the coefficients of correlation and determination according to ANVISA (guide no. 899-2003) using BioStat 5.0. The data obtained from the Yohimbine solution at $18,22,24,26$, and $28 \mu \mathrm{g} / \mathrm{mL}$ were employed to determine the calibration curve, the correlation coefficient, and the linear regression equation.

The accuracy of the method was determined by measuring, in the same day and in triplicate, the absorbance of three Yohimbine solutions at $16 \mathrm{mg} / \mathrm{mL}$ (low), $20 \mathrm{mg} / \mathrm{mL}$ (intermediate), and $28 \mathrm{mg} / \mathrm{mL}$ (high) using UV spectroscopy at $281 \mathrm{~nm}$. The intermediate precision of the method was determined applying the same procedure used for the method accuracy but on different days and by two different analysts. Accuracy may be expressed as relative standard deviation (RSD) or variation coefficient (VC\%). The limits of detection and quantification were estimated in $\mu \mathrm{g} / \mathrm{mL}$.

The feature considered for evaluating the robustness of the method was the solvent methanol from different suppliers (solvent 1 and solvent 2). The results were corroborated by ANOVA.

After validation of the method, the total alkaloids fraction present in the aqueous extract of H. lancifolius was quantified using the straight equation obtained from the calibration curve.

The statistics treatment was made using BioStat 5.0.

\section{Results and Discussion}

The isolation of Yohimbine from H. lancifolius by Lopes [12], the detection of this alkaloid in the analyzed tincture, by coinjection experiments, and the observation of an absorption maximum by $281 \mathrm{~nm}$ in the UV spectroscopic analysis of the alkaloid fraction, attributable to Yohimbine [13], justify choice of this substance as reference and this absorption maximum as parameter for the validation process. This substance is one of the already known main indole alkaloids, which are present in Apocynaceae [14] and which is available on the market as reference chemical substance (RCS).

3.1. Selectivity. Figure 1 shows a section of the UV spectra obtained from the alkaloid fraction of $H$. lancifolius $(30 \mu \mathrm{g} / \mathrm{mL})$ (a), Yohimbine hydrochloride $(22 \mu \mathrm{g} / \mathrm{mL})$ (b), and methanol (c) in the region between 200 and $400 \mathrm{~nm}$, showing the absorption maxima at $281 \mathrm{~nm}$ of Yohimbine 


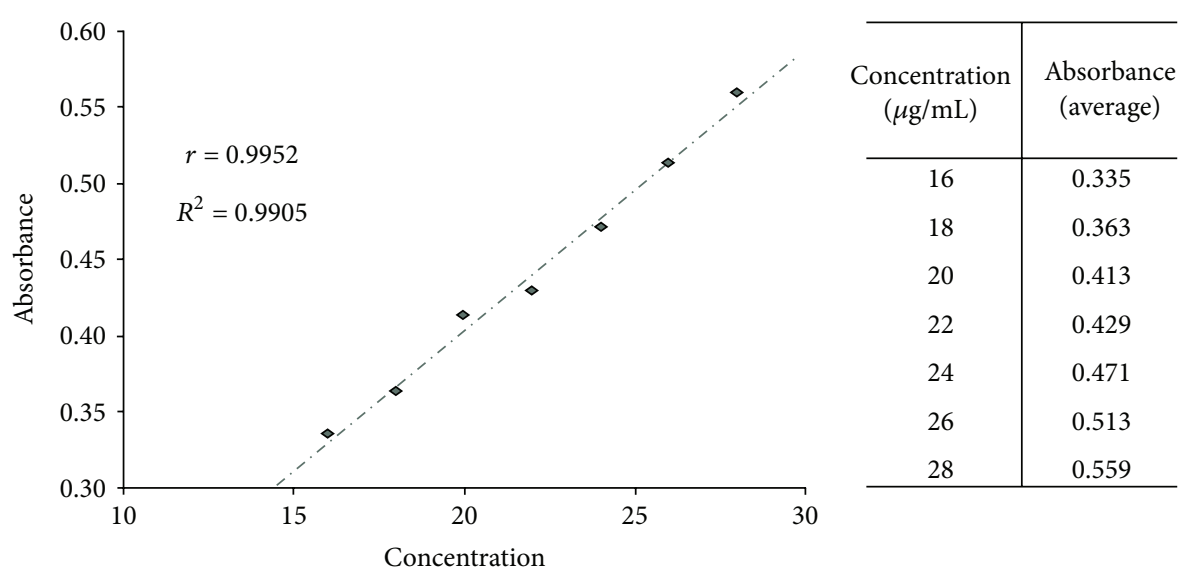

FIGURE 2: Graphical representation of the method linearity for Yohimbine in methanol at $281 \mathrm{~nm}$.

and alkaloid fraction. This indicates that this wavelength is selective for the quantification of the reference substance and the alkaloid fraction even in the presence of the selected solvent.

3.2. Linearity. The spectrophotometric method developed at $281 \mathrm{~nm}$ shows linear correlations at the concentrations studied. Figure 2 shows the linearity, the coefficient of determination $\left(R^{2}\right)$ and of correlation $(r)$ of the method for Yohimbine.

The determination of the correlation coefficient is not enough to ensure the absolute linearity of the calibration curve since the analytical signal can show high residue or include unevenly distributed points along the calibration range [15]. Therefore, the analysis of the data used to determine the calibration curve must show a constant variance (homocedastity) and absence of atypical samples (here concentration values) with a uniform distribution of residues, with zero mean, designing a homogeneous distribution of the points along the axes of the graph indicating that the curve is straight linear (Figure 3).

3.3. Calibration Curve. Figure 4 depicts the analytical curve, its straight equation, and the Pearson correlation coefficient $(r)$ for yohimbine. $R^{2}=0.9905$ is the coefficient of determination, which confirms the suitability of the method to the range considered $(16-28 \mu \mathrm{g} / \mathrm{mL})$.

3.4. Precision and Accuracy. The data repeatability (intrarun), intermediate precision (interrun), and accuracy are shown in Table 1 where the values of relative standard deviation can be observed ranging from $0.19 \%$ to $2.09 \%$ and accuracy values are found between $98 \%$ and $102.90 \%$. Brazilian regulation states that the variation of precision cannot exceed 5\% and the accuracy should not be less than 95\% [16].

The experimental data confirm that the proposed method for the quantification of total alkaloids in the aqueous extract of H. lancifolius by UV spectrophotometry is in accordance with current legislation and provides reliable results.

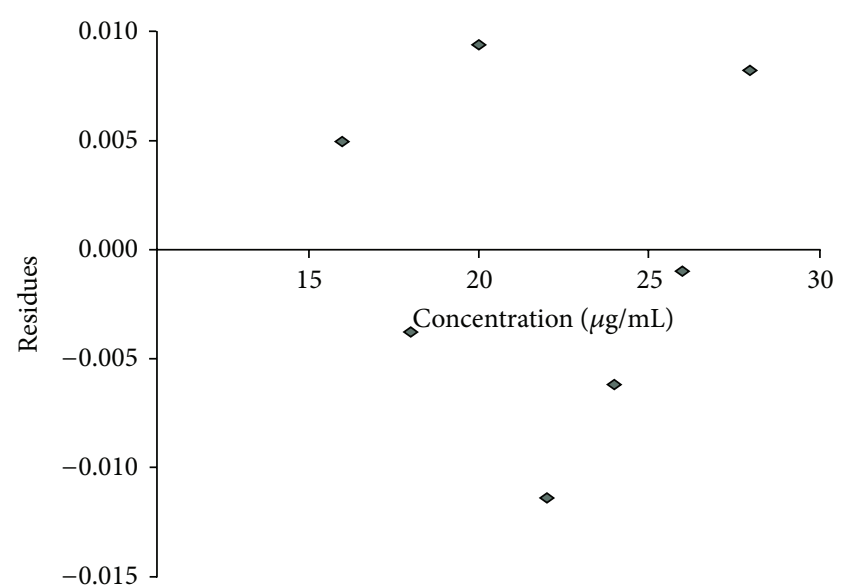

FIGURE 3: Graphical representation of data residues used to determine the method linearity for solutions of Yohimbine at 16, 18, 20, $22,24,26$, and $28 \mu \mathrm{g} / \mathrm{mL}$.

The detection limit of the method is estimated in $4.59 \mu \mathrm{g} / \mathrm{mL}$ and the quantification limit in $15.306 \mu \mathrm{g} / \mathrm{mL}$.

3.5. Robustness. No spectral data variation can be observed when solutions of Yohimbine are prepared with solvents of different brands, so $281 \mathrm{~nm}$ remains the selected absorption maximum for the method. The data are demonstrated in Table 2 and were statistically treated by ANOVA, revealing $P=0.5694(P>0.05)$, thus demonstrating that this is a robust method.

3.6. Quantification of Total Alkaloids Fraction Application of the Proposed Method in Triplicate. The analysis of a $30 \mu \mathrm{g} / \mathrm{mL}$ methanol solution of the alkaloid fraction obtained from an aqueous extract of $H$. lancifolius using the proposed method here allowed determining the amount of total alkaloids present in the sample. The average absorbance measured is 0.462. The results are shown in Table 3 . 


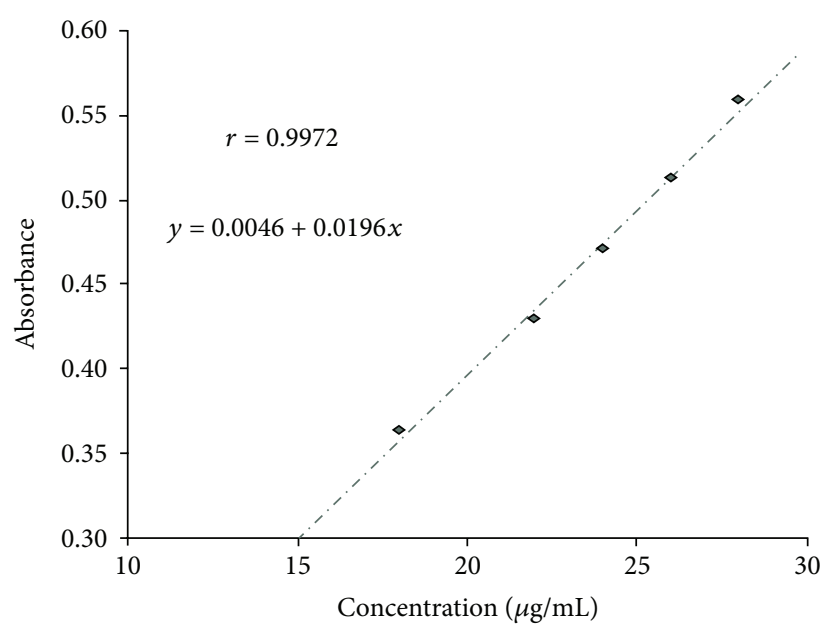

\begin{tabular}{c|c}
\hline $\begin{array}{c}\text { Concentration } \\
(\mu \mathrm{g} / \mathrm{mL})\end{array}$ & $\begin{array}{c}\text { Averaged } \\
\text { absorbance }\end{array}$ \\
\hline 18 & 0.363 \\
22 & 0.429 \\
24 & 0.471 \\
26 & 0.513 \\
28 & 0.559 \\
\hline
\end{tabular}

FIGURE 4: Graph of the calibration curve obtained with solutions of Yohimbine considering the average absorbance for each concentration.

TABLE 1: Data of repeatability, intermediate precision, and accuracy of the developed UV spectrophotometric method for determination of total alkaloids in aqueous extract of $H$. lancifolius.

\begin{tabular}{|c|c|c|c|c|c|c|}
\hline Assay & Calculated concentration $(\mu \mathrm{g} / \mathrm{mL})$ & $N$ & $C(\mu \mathrm{g} / \mathrm{mL})$ & SD & RSD (\%) & $A(\%)$ \\
\hline \multirow{3}{*}{ Repeatability } & 16 & 3 & 15.698 & 0.030 & 0.19 & 98.00 \\
\hline & 20 & 3 & 19.864 & 0.181 & 0.90 & 99.32 \\
\hline & 28 & 3 & 27.724 & 0.392 & 1.41 & 99.01 \\
\hline \multirow{3}{*}{$\begin{array}{l}\text { Intermediary } \\
\text { precision } \\
\text { day } 1\end{array}$} & 16 & 3 & 16.448 & 0.205 & 1.25 & 102.80 \\
\hline & 20 & 3 & 20.580 & 0.257 & 1.25 & 102.90 \\
\hline & 28 & 3 & 28.373 & 0.245 & 0.86 & 101.33 \\
\hline \multirow{3}{*}{$\begin{array}{l}\text { Intermediary } \\
\text { precision } \\
\text { day } 2\end{array}$} & 16 & 3 & 16.213 & 0.339 & 2.09 & 101.33 \\
\hline & 20 & 3 & 20.345 & 0.054 & 0.27 & 101.72 \\
\hline & 28 & 3 & 28.391 & 0.271 & 0.96 & 101.39 \\
\hline
\end{tabular}

$C$ = averaged concentration from $N$ determinations; $\mathrm{SD}=$ standard deviation; $\mathrm{RSD}(\%)=$ relative standard deviation; $A(\%)=$ accuracy.

TABLE 2: Data of the robustness of the developed UV spectrophotometric method for the determination of total alkaloids in the aqueous extract of $H$. lancifolius.

\begin{tabular}{lcccc}
\hline Calculated concentration $(\mu \mathrm{g} / \mathrm{mL})$ & Solvent & $N$ & $C(\mu \mathrm{g} / \mathrm{mL})$ & Absorbance \\
\hline 16 & 1 & 3 & 16.448 & 0.293 \\
20 & & 3 & 20.580 & 0.373 \\
28 & 2 & 3 & 28.373 & 0.523 \\
\hline 16 & 2 & 3 & 16.217 & 0.261 \\
20 & & 3 & 19.651 & 0.315 \\
28 & & 3 & 28.141 & 0.449 \\
\hline
\end{tabular}

$C=$ average concentration of $N$ determinations.

TABLE 3: Amount of total alkaloids in the herbal drug, in dried grinded bark (I), in dried aqueous extract (II), and in the alkaloid fraction (III).

\begin{tabular}{lcccc}
\hline Material & Drug & Dried aqueous extract & Alkaloid fraction & Total alkaloid \\
\hline Peso & $25,000 \mathrm{mg}$ & $9,549 \mathrm{mg}$ & $26.74 \mathrm{mg}$ & $20.80 \mathrm{mg}$ \\
\hline I & $100 \%$ & & & $0.0832 \%(832 \mathrm{ppm})$ \\
II & & $100 \%$ & $100 \%$ & $0.218 \%$ \\
III & & & $77.79 \%$ \\
\hline
\end{tabular}




\section{Conclusion}

The proposed quantification method was validated; it presents selectivity at $281 \mathrm{~nm}$ for the alkaloid fraction from the aqueous extract of $H$. lancifolius, providing reliability for the quantitation of total alkaloids in the herbal drug. Besides the method robustness, according to the parameters required by the Brazilian regulation, the correlation between values of absorbance and concentration according to the straight equation obtained confirms it is a linear method. The reported quantification method here, using UV spectrophotometry at $281 \mathrm{~nm}$, shows precision and accuracy and is also accessible and easy to perform and made it possible to quantify the total alkaloids present in the aqueous extract of the plant material collected in Pará Amazonia, Brazil.

\section{Conflict of Interests}

The authors declare that there is no conflict of interests regarding the publication of this paper.

\section{Acknowledgments}

The authors are thankful to the National Council for Scientific and Technologic Development, Brazil, and Pará Amazonia Foundation for the financial support.

\section{References}

[1] M. E. Endress and P. V. Bruyns, "A revised classification of the Apocynaceae s.l," The Botanical Review, vol. 66, no. 1, pp. 1-56, 2000.

[2] A. M. Giulietti, R. M. Harley, L. P. de Queiroz, M. D. G. L. Wanderley, and C. van den Berg, "Biodiversity and conservation of plants in Brazil," Conservation Biology, vol. 19, no. 3, pp. 632639, 2005.

[3] A. Cronquist, The Evolution and Classification of Flowering Plants, The New York Botanical Garden, New York, NY, USA, 2nd edition, 1988.

[4] A. C. F. Amaral, J. L. P. Ferreira, M. L. B. Pinheiro, and J. R. A. Silva, "Monograph of Himatanthus sucuuba, a plant of Amazonian folk medicine," Pharmacognosy Reviews, vol. 1, no. 2, pp. 305-313, 2007.

[5] R. E. Woodson Jr., "Studies in the Apocynaceae: an evaluation of the genera Plumeria L. and Himatanthus Willd," Annals of the Missouri Botanical Garden, vol. 25, p. 193, 1938.

[6] Brasil, Ministério da Saúde. Agência Nacional de Vigilância Sanitária (ANVISA). Resolução da Diretoria Colegiada 10 (RDC) de 09 de março de 2010, presents provisions concerning the notification of plant drugs, Brasília, Brazil, 2010.

[7] Brasil, Ministério da Saúde. Agência Nacional de Vigilância Sanitária (ANVISA). Resolução da Diretoria Colegiada 14 (RDC) de 31 de março de 2010, presents the Rules on the registration of herbal medicines. Brasília: MS, 2010.

[8] G. L. Cruz, Dicionário das Plantas Úteis do Brasil, Editora Civilização Brasileira S. A., Rio de Janeiro, Brazil, 3rd edition, 1985.

[9] S. S. Mengue, E. P. Schenkel, L. A. Mentz, and M. I. Schmidt, "Especies vegetales utilizadas por embarazadas con el objeto de provocar La menstruación (Encuesta a siete ciudades de
Brasil)," Acta Farmacéutica Bonaerense, vol. 16, no. 2, pp. 251258, 1997.

[10] Farmacopéia Brasileira, Part I, 4th edition, 1988.

[11] Farmacopéia Brasileira, Part I, 1926.

[12] J. F. Lopes, Ioimbina e uleina isolados de Himatanthus lancifolius (Muell. Arg.) Woodson, Apocynaceae [M.S. thesis], Universidade Federal do Paraná, Curitiba, Brazil, 2008, dspace.c3sl.ufpr.br/ dspace/bitstream/.../Juliano\%20Ferreira\%20Lopes.pdf.

[13] A. J. B. Oliveira, Estudo de quatro espécies do gênero Aspidosperma por cromatografia gasosa de alta resolução acoplada à espectrometria de massas [M.S. thesis], Universidade Estadual de Campinas, São Paulo, Brazil, 1994, http://biq.iqm.unicamp.br/ arquivos/teses/ficha21388.htm.

[14] W. M. Souza, Estudo químico e das atividades biológicas dos alcaloides indólicos de Himatanthus lancifolius (Muell. Arg) Woodson, Apocynaceae (agoniada) [Ph.D. thesis], Universidade Federal do Paraná, Curitiba, Brazil, 2008.

[15] F. A. L. Ribeiro, M. M. C. Ferreira, S. C. Morano, L. R. da Silva, and R. P. Schneider, "Planilha de validação: uma nova ferramenta para estimar figuras de mérito na validação de métodos analíticos univariados," Química Nova, vol. 31, no. 1, pp. 164-171, 2008.

[16] Brasil, RE no 899 de 29 de maio de 2003, "presents the Guide for validation of analytical and bioanalytical methods," Ministério da Saúde. Agência Nacional de Vigilância Sanitária, http://elegis.anvisa.gov.br/. 

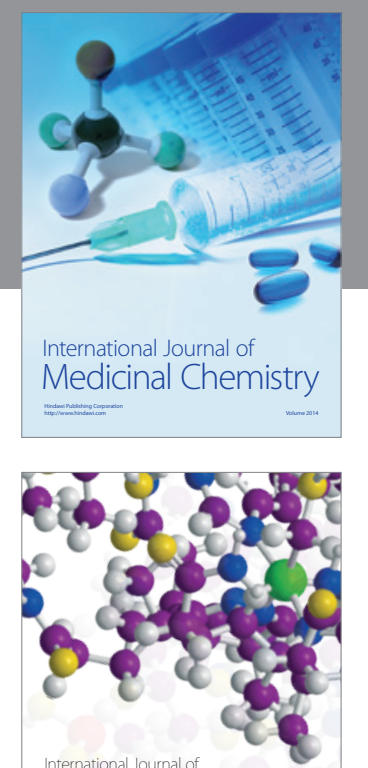

\section{Carbohydrate} Chemistry

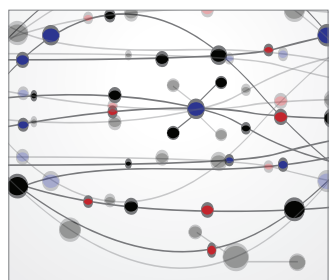

The Scientific World Journal
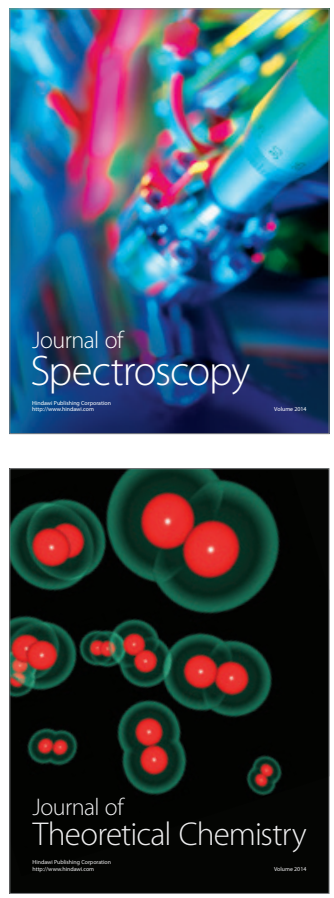
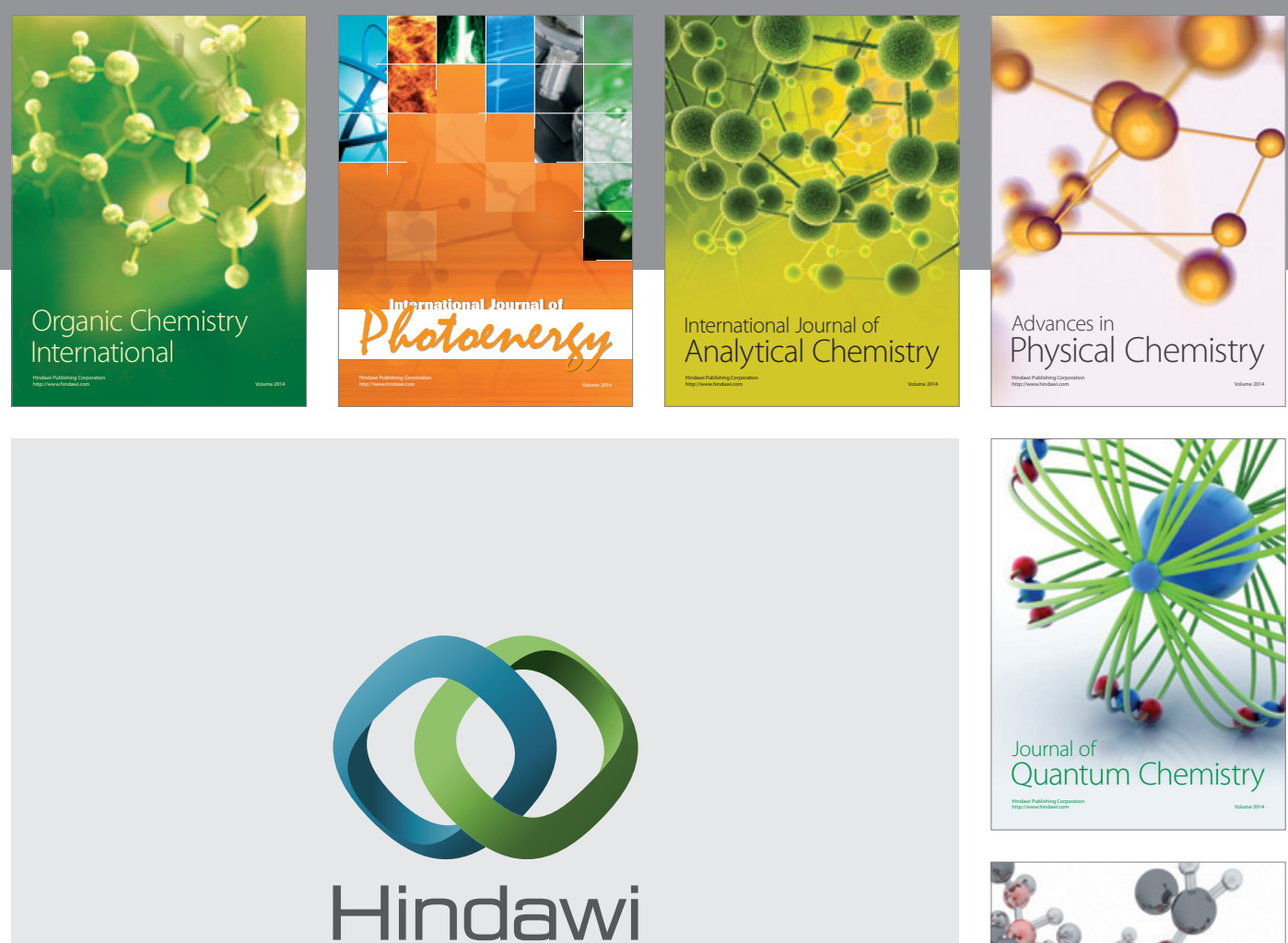

Submit your manuscripts at

http://www.hindawi.com

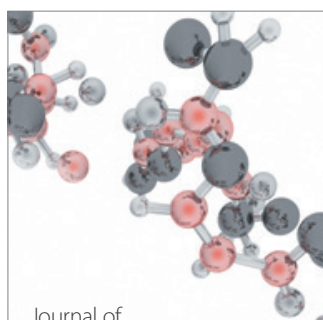

Analytical Methods

in Chemistry

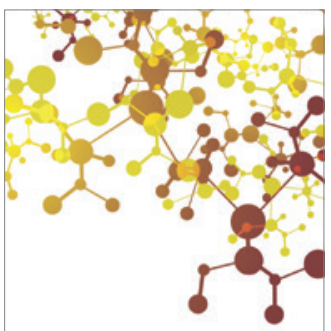

Journal of

Applied Chemistry

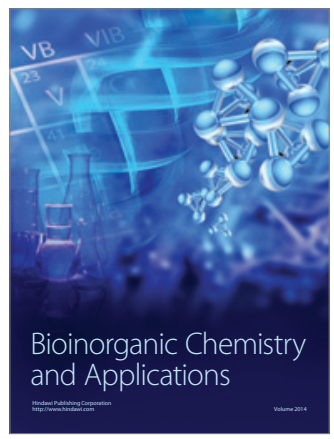

Inorganic Chemistry
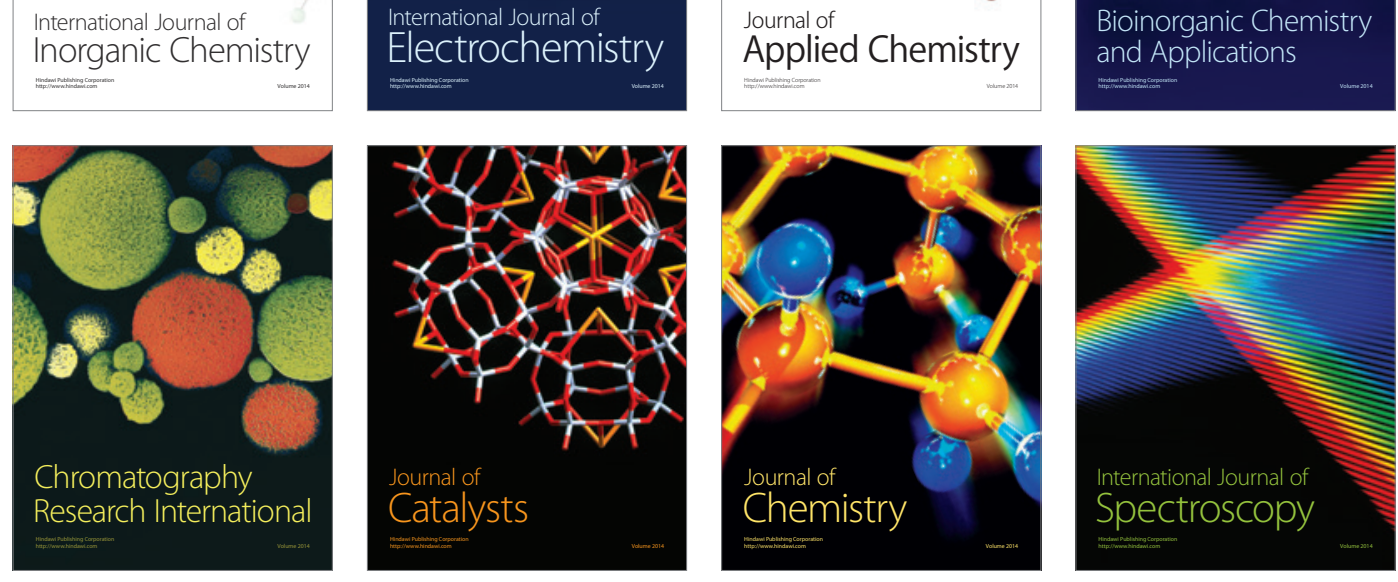